\title{
EXTRACTION AND MICRONIZATION OF EDESTIN FROM HEMP SEED
}

\author{
Milos BERAN, Ondrej VLTAVSKY, Josef DRAHORAD \\ Food Research Institute Prague, Prague, Czech Republic, EU, m.beran@vupp.cz
}

https://doi.org/10.37904/nanocon.2020.3724

\begin{abstract}
Protein edestin extraction from hemp seed press cakes obtained after a cold press oil extraction process has been optimized at laboratory scale and verified in a pilot plant experiment. Subsequent water and brine extraction of the disintegrated hemp seed press cake was used to obtain the water-soluble albumin protein fraction and the brine-soluble globulin fraction - edestin. Isoelectric precipitation was used to obtain the proteins from the extraction solutions. New Carbon Dioxide Assisted Spray Nebulisation Drying (CASND) technology has been used to dry and micronize the protein concentrates and isolates. The protein powders were in form of hollow spheres with average particle diameter about $600 \mathrm{~nm}$. The particles were characterized by the SEM method. The protein microparticulation allows to improve foaming and emulsifying properties and formation of long-term stable water dispersions.
\end{abstract}

Keywords: Hemp seed, protein concentrates, protein isolates, microparticulation, Carbon Dioxide Assisted Spray Nebulisation Drying

\section{INTRODUCTION}

Protein in food is an essential nutrient which comes from animal and plant sources. Besides the nutritional value, the functional properties of food proteins affect behavior in food systems and influence the quality attributes, structure, texture, mouth-feel, and flavor of the final product. Plant proteins can differ from animal proteins in terms of digestibility, amino acid composition, and the presence of antinutritional factors [1]. Most evidence suggests that a shift to largely plant-based protein diets would reduce chronic disease risks among industrialized and rapidly-industrializing populations. Filter cakes from canola / rapeseed, sunflower and hemp seeds obtained after oil pressing and extraction, rice, cell fluids obtained from potatoes, or pea seeds belong among the main alternative sources of commercially available plant protein concentrates and isolates for human nutrition. Hemp seed contains the salt-soluble globulin edestin $(\sim 75 \%)$ and the water-soluble albumins $(\sim 25 \%)$ as the main storage proteins. Edestin is a hexameric legumin protein of hemp seed with globular structure of $11 \mathrm{~S}$ type and molecular weight approximately $300 \mathrm{kDa}$. Hemp seed proteins have a high level of arginine and a sulfur-rich protein fraction, two unique features that impart high nutritional values [2]. Hemp proteins have a protein digestibility-corrected amino acid score equal to or greater than certain grains, nuts, and some pulses [3]. Hemp seed enzymatic hydrolysates have also proven effective during in vitro and in vivo tests as antioxidant and antihypertensive agents. Therefore, hemp seed proteins and hydrolysates have the potential to be used as ingredients to formulate functional foods [2,4]. Spray drying is usually used to produce powders from the protein rich solutions. Freeze drying is alternative drying technique, which is used less frequently because of higher price and limited capacity. Functional properties of proteins in food matrices are determined by the physicochemical properties of the proteins, degree of denaturation, type of processing, and particle morphology and size, in the case of powdered proteins with limited solubility. The design of protein particles with tailored properties has received an increased attention recently. Control of particle size, morphology, surface and internal properties is crucial for obtaining protein particles with the necessary properties for emerging applications. Singer et al. [5] originally patented the use of whey protein microparticles, formed by thermal aggregation at high shear and low pH. A commercial fat replacer SIMPLESSE $®$, based on 
this process, was launched by NutraSweet in 1988 in form of spherical particles in the size range of $0.1-2.5$ $\mu \mathrm{m}$. The initial patent was later extended to other proteins, e.g., bovine serum albumin, egg white albumin and soy protein [6]. SIMPLESSE $®$ has been applied in dressings and mayonnaise, frozen desserts, cheese and other dairy products since that time [7]. The improved creaminess obtained by use of microparticulated protein products was due to particles $<5 \mu \mathrm{m}$ in size, mimicking emulsion droplets $[8,9]$. The preparation provides emulsion and foam stabilization, heat and $\mathrm{pH}$ stability, texture, creaminess and smoothness in a wide range of full-fat and low-fat applications. Two approaches, namely, isoelectro-mechanical and thermo-mechanical processes, are most often used in microparticulation of protein. In these processes, conditions that denature (i.e. heat) or induce a complex or precipitate formation (i.e. isoelectric precipitation) are combined with a strong mechanical treatment, e.g. high share rates or turbulence and cavitation to produce nanoaggregated protein microparticles of desired size and distribution. Several methods, from simple heat treatment in dilute systems to the combination of heat and mechanical treatments in concentrated protein solutions, have been used to obtain protein particles with varying functional properties [10]. Turbulation, cavitation and shear are also the main phenomena encountered in high-pressure homogenizers, such as microfluidizers. The microfluidization technology is an unique type of high-pressure homogenization [11,12]. Alternative processes may also be implemented, such as extrusion cooking at acid pH [13], or two-step emulsification of whey protein isolate in sunflower oil containing polyglycerol polyricinoleate with subsequent heating and oil removal [14]. Supercritical fluid assisted atomization processes are other technologies of choice to produce microparticalated proteins [15]. Carbon Dioxide Assisted Spray Nebulisation Drying (CASND) technology, shortly Spray Nebulisation Drying (SND) is a new emerging technology described recently [16]. The technology combines the spray drying technology, when the liquid to be dried is atomized by a rotary atomizer, with carbon dioxide assisted nebulization process in an original way. A wide range of application forms - low density particles, composite particles, sterically stabilized liposomes, phytosomes, microencapsulated particles or microbial cells, solid dispersions, dried single and multiple emulsions, nano- and microfibers and other - can be produced by this process.

\section{MATERIALS AND METHODS}

\subsection{Material}

Hemp seed press cake (Benico variety) was purchased from KONOPRO company (Czech Republic). All other chemicals were purchased from VWR International s.r.o. (Czech Republic).

\subsection{Extraction of hemp proteins from the dried filter cake}

\section{Laboratory extraction experiment}

We have used a modified method according to K. Bailey [17]. Subsequent water and brine extraction of the disintegrated hemp seed press cake was used. Isoelectric precipitation was harnessed to obtain the proteins from the extraction solutions. The dried press cake of hemp seeds was pulverized with a knife blender Catler 800 series (Catler, Australia). Water extraction at $45^{\circ} \mathrm{C}$ in Series 25 Incubator Shaker (New Brunswick Scinces) at $300 \mathrm{rpm}$ was used to remove albumin fraction and soluble impurities from the pulverized hemp seed press cake. An insoluble sediment was obtained by centrifugation with Rousselet Robatel RA20 Vx centrifuge (Rousselet Robatel, Annonay, France), 4000 rpm. The sediment was extracted two times with surplus of 10\% brine solution at $45^{\circ} \mathrm{C}$ in the shaker at $300 \mathrm{rpm}$ overnight to obtain the globulin edestin fraction. Isoelectric precipitation at $\mathrm{pH} 4,00$ was used to separate edestin from the brine solution. Precipitated edestin was obtained in the sediment fraction after centrifugation in HERMLE Z513 K centrifuge at $5000 \mathrm{rpm}$ (RCF $6500 \times \mathrm{g}$ ), resuspended in distilled water and separated by repeated centrifugation. The washed edestin was resuspended in distilled water and micronized and dried simultaneously by Spray Nebulisation Drying (SND) process in Atomizer pilot-plant demonstrator. Figure $\mathbf{1}$ shows the process of the isoelectric precipitation of edestin from the brine extraction solution. 


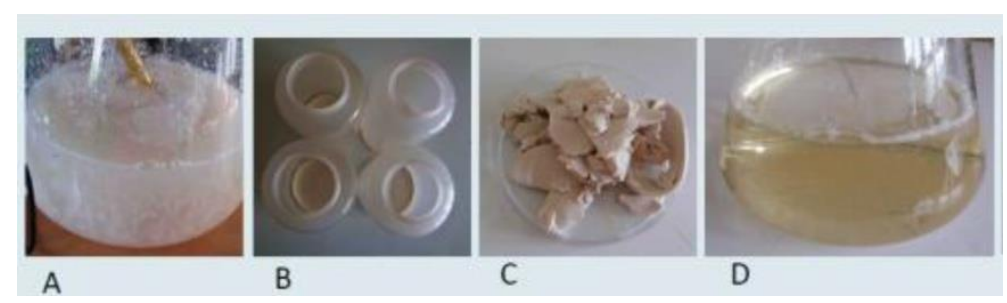

Figure 1 Isoelectric precipitation of edestin from the brine extraction solution

\section{Pilot plant extraction experiment}

The extraction process was scaled-up in the The Biotechnological Pilot-Plant of the Institute of Microbiology of the Czech Academy of Sciences. Continuous disk-bowl centrifuge BTPX 205 (Alfa Laval) was used to separate the fibrous sediment after the extraction process and tubular-bowl centrifuge Sharples was used to separate the precipitated edestin.

\subsection{Drying and microparticulation of the plant protein extracts}

The SND combines the spray drying technology, when the liquid to be dried is atomized by a rotary atomizer, with carbon dioxide assisted nebulization process in an original way. The rotary atomizer used for the SND technology has an unique patented construction allowing to regulate and keep the outlet pressure at an exactly defined level. A solution, emulsion or suspension is saturated by carbon dioxide at pressure 6-8 MPa before the drying process. The atomization process takes place in two steps. In the first step, primary droplets are produced by the centrifugal force at the outlet of the rotary atomizer of special construction. In the second step, the primary droplets are divided into secondary droplets by the $\mathrm{CO} 2$ expansion from the inside of primary droplets. The secondary droplets, usually in the form of micro-bubbles, are rapidly dried by warm air stream at temperatures up to $60^{\circ} \mathrm{C}$ and solid particles are formed in a drying chamber. Electrofilter separator AEROFOG KE1 (Vzduchotechnik, Czech Republic) has been used to separate the powder from the air stream. Simultaneous pressure homogenization and drying of the washed edestin paste resuspended in distilled water was carried out using the nebulization unit of the Atomizer pilot plant demonstrator (DBH Technologies, Czech Republic) under following conditions: Liquid flow rate, $20 \mathrm{ml} \cdot \mathrm{min}^{-1}$; Carbon dioxide flow rate, 1,8 $\mathrm{ml} \cdot \mathrm{min}^{-1}$; Pressure, $6 \mathrm{MPa}$; Inlet air temperature, $60^{\circ} \mathrm{C}$; Outlet air temperature, $48^{\circ} \mathrm{C}$; Air flow rate: $1000 \mathrm{~m}^{3} \cdot \mathrm{h}^{-1}$.

\subsection{Characterisation of the protein microparticles by scanning electron microscopy}

Scanning Electron Microscopy (SEM) was used to analyze the particle sizes and morphologies. The samples of the fibres were fixed with a double-faced adhesive tape to the holders and evaluated in a Phenom G2 scanning electron microscope (Phenom-World BV, Eindhoven, Netherlands).

\section{RESULTS and DISCUSSION}

\subsection{Extraction of hemp proteins from the dried filter cake}

\section{Laboratory extraction experiment}

Material balance of the experiment

Input: $900 \mathrm{~g}$ of the disintegrated hemp seed press cake. DM 93,68\%, Protein content $33,09 \%(\mathrm{w} / \mathrm{w})$. Total pure protein input: $297,8 \mathrm{~g}$.

Output:

1) extraction yield: $272,88 \mathrm{~g}$ of edestin paste; DM $20.3 \pm 1.0 \%$; Protein content: $18,2 \pm 5.0 \%$; Protein content $89,66 \%$ in DM. 
2) extraction yield: $251,90 \mathrm{~g}$ of edestin paste; DM 17,2 $\pm 1.0 \%$; Protein content: $15,0 \pm 5.0 \%$; Protein content $87,21 \%$ in DM.

Total pure edestin protein yield $87,44 \mathrm{~g}$. Total protein edestin recovery: $29,36 \%$.

The obtained edestin recovery from the hemp seed press cake has been relatively low, about $30 \%$. There is a significant part of edestin, which can't be extracted under the condition of the technological process. Edestin binding to a water-insoluble polysaccharide fiber is a probable explanation of the limited effectiveness of the extraction process. There are no published studies presenting yields of brine extraction of edestin from hemp seeds to compare with.

\section{Pilot plant extraction experiment}

Material balance of the experiment

Input: $10 \mathrm{~kg}$ of disintegrated hemp seed press cake. DM 92,1\%, Protein content 30,69\%. Total pure protein input: $3069 \mathrm{~g}$.

Output:

Total extraction yield was $1,79 \mathrm{~kg}$ of a dense edestin sediment after centrifugation; DM $56,1 \%(\mathrm{w} / \mathrm{w})$; Protein content $90,92 \%(\mathrm{w} / \mathrm{w}$ ) of DM. The total pure edestin yield: $0,91 \mathrm{~kg}$ from $10 \mathrm{~kg}$ of (wet matter) hemp seed press cake.

\section{Total protein edestin recovery: $29,65 \%$.}

Using a high-quality industrial centrifuge allows obtaining a dense edestin sediment (DM 56,1\%) with high protein content (about $90 \%$ of DM). The total yield of the pilot plant extraction experiment was at least comparable with the laboratory experiment yields. The technological process is relatively simple and cheap. Except $\mathrm{NaCl}$, there is no significant consumption of other chemicals.

\subsection{Drying and microparticulation of the plant protein extracts}

Simultaneous pressure homogenization and drying of the washed edestin paste resuspended in distilled water was successfully demonstrated using the Atomizer pilot plant demonstrator. Our experiments proved high filtration efficiency of the electrofilter with the protein isolate particles produced by the SND process (Figure 2,C). Edestin dried and micronized sample is shown in Figure 2,D. However, the product yield of the SND process could not be calculated. The reason was that the AEROFOG KE1 electrofilter is not suitable for quantitative recovery of powdered products, because of the small gaps in between the collecting electrodes (Figure 2,C). The electrofilter was constructed as an air purifier to remove aerosol particles from air stream. The results inspired a development of a new electrostatic fine powder precipitator which has already been constructed with the aim to facilitate the maximal recovery of the products powdered by the SND technology. The electrostatic fine powder precipitator is tested at present time with hopeful results.

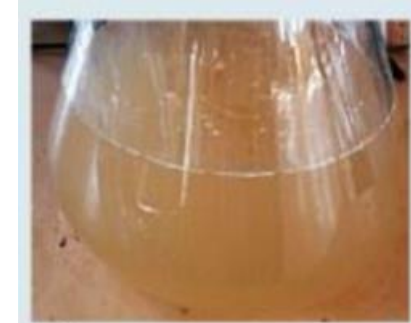

A

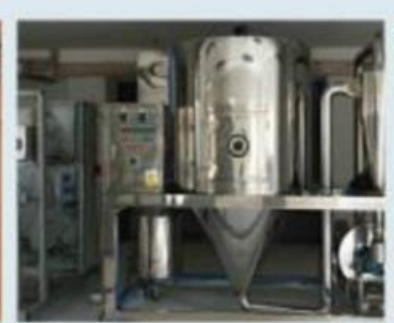

B

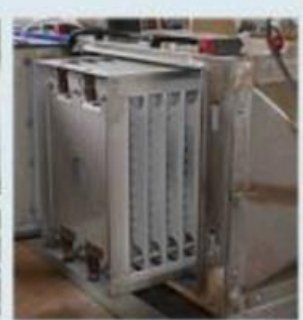

C

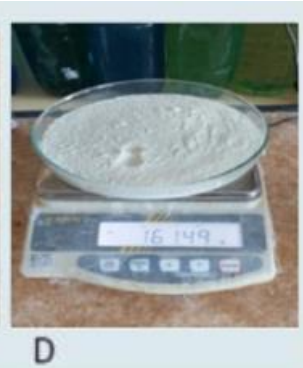

D

Figure 2 A: washed edestin paste resuspended in DEMI water B: pilot plant demonstrator Atomizer, C: electrofilter ionizing module for powder separation, D: edestin micronized sample 


\subsection{Characterisation of the protein microparticles by scanning electron microscopy}

Comparison of microstructures of the hemp seed protein isolate dried with the ATOMIZER demonstrator and the same sample dried with a conventional spray dryer is shown in Figure 3. There is a visible difference between both the samples perceptible in the SEM images. Both the samples consist of hollow nanospheres or microspheres, but the average size of the particles obtained by the SND process is much lower.

Previous experiments [16] showed, that the mean value of the aerosol particle size distribution measured in the drying chamber is about $600 \mathrm{~nm}$. The interval of the particle size distribution is relatively wide. The aerosol inside the drying chamber contains significant amount of nanoparticles smaller than $100 \mathrm{~nm}$, but a small portion of microparticles up to several micrometers, too. The microparticulation of the protein concentrates by the SND process resulted in statistically significant improvement of the foaming capacity and stability, emulsifying activity and emulsion stability [16].
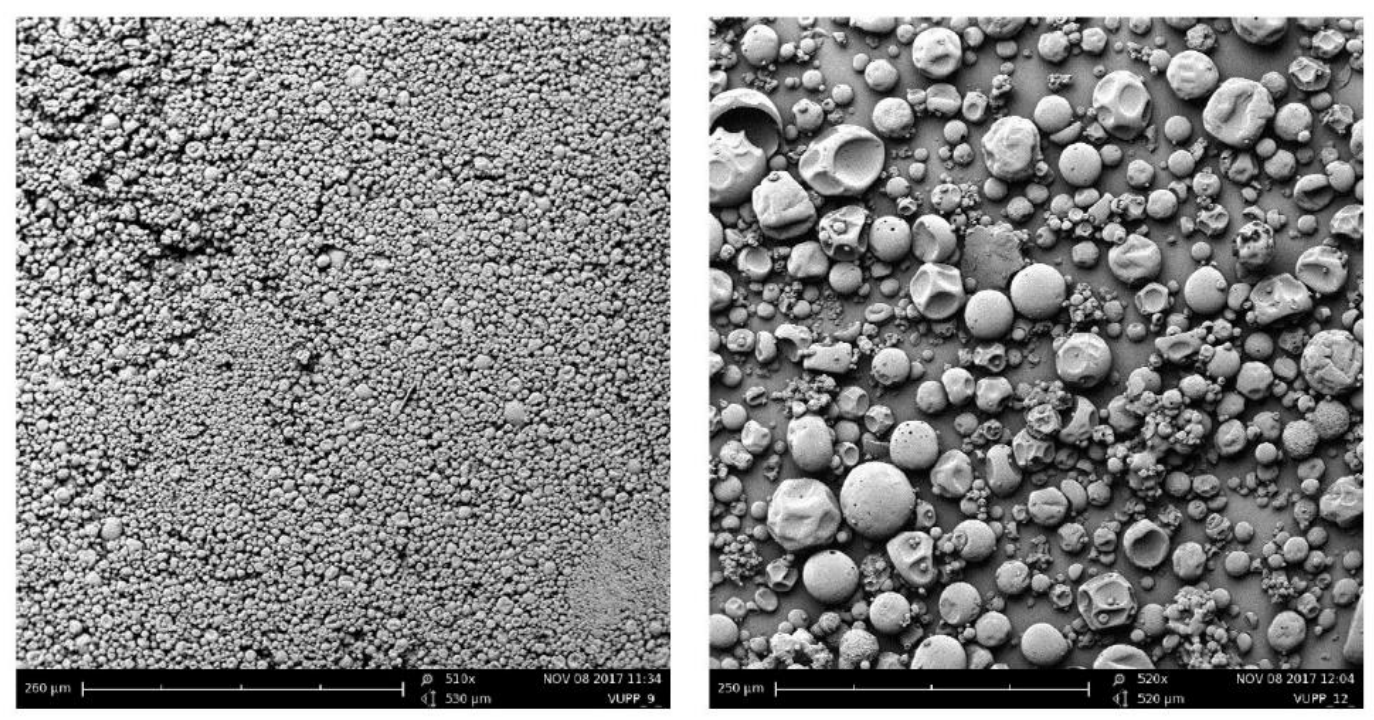

Figure 3 Comparison of SEM images of edestin micronized by the spray nebulisation drying technology (left) and dried by conventional spray drying technology (right), line segment $260 \mu \mathrm{m}$

\section{CONCLUSIONS}

Edestin yields were about $10 \%(\mathrm{w} / \mathrm{w})$ from the input DM of hemp seed press cake, and edestin recovery was about $30 \%(\mathrm{w} / \mathrm{w})$. Edestin strong binding to a polysaccharide fiber is a probable explanation of the limited effectiveness of the extraction process. Using a high-quality industrial centrifuge allows obtaining a dense edestin sediment (DM 56,1\%) with high protein content (about $90 \%$ of DM). The total yield of the pilot plant extraction experiment was at least comparable with the laboratory experiment yields. The technological process is relatively simple and cheap. Except $\mathrm{NaCl}$, there is no significant consumption of other chemicals. The SND technology allows to produce protein concentrates or isolates in a form of submicron hollow spheres with improved functional properties. We have successfully used edestin in several products, including gluten free baguettes and high-protein food products, such as crackers, muffins and protein smoothies. All the products are in compliance with the EFSA nutritional claim for high-protein food products. The products were positively accepted in sensory analysis. No foreign unpleasant taste was noticed.

\section{ACKNOWLEDGEMENTS}

This work was supported by the TACR project number TH03010019 and by the Institutional Development Fund RO0320 of FRIP provided by the Ministry of Agriculture of the Czech Republic 


\section{REFERENCES}

[1] GUEGUEN, J., POPINEAU, Y. Plant proteins from European crops: food and non-food applications. SpringerVerlag Berlin Heidelberg, 1998, p. 339.

[2] NADARTHUR, S., WANASUNDARA, J.P.D., SCANLIN, L. Sustainable protein sources. Academic Press, 2016, pp: 456.

[3] HOUSE J.D., NEUFEKD, J., LESON, G. Evaluating the quality of protein from hemp seed (Cannabis sativa L.) products through the use of the protein digestibility-corrected amino acid score method. J Agric Food Chem. 2010, vol. 58, pp. 11801-11807.

[4] MALOMO, A.S, ALUKO, R.E. Conversion of a low protein hemp seed meal into a functional protein concentrate through enzymatic digestion of fibre coupled with membrane ultrafiltration. Innov Food Sci Emerg Technol. 2015, vol 31, pp. 151-159.

[5] SINGER, N.S., YAMMAMOTO, S., LATTELA, J. Protein product base. Patent US 4734287. John LaBatt Limited, London, ON, Canada, 1988.

[6] SINGER, N.S., YAMMAMOTO, S., LATTELA, J. Protein product base. Patent US 4734287. John LaBatt Limited, London, ON, Canada, 1988.

[7] CHEFTEL, J.C., DUMAY, E. Microcoagulation of proteins for development of creaminess. Food Rev Int. 1993, vol. 9, pp. 473-502.

[8] SINGER, N.S., DUNN, J.M. Protein microparticulation: the principle and the process. J Am Coll Nutr. 1990, vol. 9, pp. 388-397.

[9] IPSEN, R. Microparticulated whey proteins for improving dairy product texture. Int Dairy. 2017, vol. J 67, pp. 73-79.

[10] SAĞLAM, D., VENEMA, P., VAN DER LINDEN, E., DE VRIES, R. Design, properties, and applications of protein micro- and nanoparticles. Curr Opin Colloid Interface Sci. 2014, vol.19, pp. 428-437.

[11] DAMADORAN, S. Food proteins and their applications. Routledge, 2017, p. 694.

[12] DISSANAYAKE, M., VASILJEVIC, T. Functional properties of whey proteins affected by heat treatment and hydrodynamic high-pressure shearing. J Dairy Sci. 2009, vol 92, pp. 1387-1397.

[13] VIOQUE, J., SÁNCHEZ-VIOQUE, R., CLAMENTE, A., PEDROCHE, J, MILLÁN, F. Partially hydrolyzed rapeseed protein isolates with improved functional properties. J Am Oil Chem Soc. 2000, vol. 77, pp. 447-450.

[14] SAĞLAM D, VENEMA P, DE VRIES R, SAGIS LMC, VAN DER LINDEN E. Preparation of high protein microparticles using two-step emulsification. Food Hydrocolloids. 2011, vol. 25, no. 5, pp. 1139-1148.

[15] YEO, S.D., LIM, G.B., DEBENDETTI, P.G., BERSTEIN, H. Formation of microparticulate protein powder using a supercritical fluid antisolvent. Biotechnol Bioeng. 1993, vol. 41, pp. 341-346.

[16] BERAN, M., DRAHORAD, J., VLTAVSKY, O., URBAN, M., LAKNEROVA, I., FRONEK, M., SOVA, J., ONDRACEK, J., ONDRACKOVA, L., KRALOVA, M., FORNANKOVA, S. Pilot-Scale Production and Application of microparticulated Plant Proteins. J Nutr Food Sci. 2018, vol. 8, p. 655.

[17] BAILEY, K. The denaturation of edestin by acid: T. B. Osborne's edestan. Biochem J. 1942, vol. 36, no 1-2, pp. 140-154. 